\title{
Validity Evidence for the Flow State Scale-2 with University Athletes
}

\author{
Jose Augusto Evangelho Hernandez ${ }^{1}$ (1) http://orcid.org/0000-0001-9402-7535 \\ Rogério da Cunha Voser ${ }^{2}$ (1) https://orcid.org/0000-0001-5946-6989
}

\begin{abstract}
Flow is an optimal psychological state, a very positive experience associated with high levels of performance in various areas of human activity such as sports. This study sought evidence for the construct validity of the Brazilian version of FSS-2 and, in this way, contribute with theoretical and empirical resources for the research and professional practice of Brazilian psychologists in the field of sports and physical exercise. This instrument provides a global measure and specifically measures nine dimensions of the flow experience. The participants were 366 athletes, men and women, 16-41 years of age, who played futsal, handball, volleyball and rugby and disputed the University Games Gaúchos 2015. The scores of the subjects were subjected to Confirmatory Factor Analysis. Indices of content, factorial, convergent and discriminant validities and internal consistency were found, discussed according to theoretical and empirical data from this line of research. We conclude that the general adjustments of the model were close to those obtained in the original studies.
\end{abstract}

Keywords: flow, test validity, sport psychology, positive psychology

\section{Evidências de Validade para a Flow State Scale-2 com Atletas Universitários}

Resumo: O flow é uma experiência muito positiva, um estado psicológico ótimo que está associado a elevados níveis de desempenho em várias áreas de atuação humana como o esporte. Este estudo buscou evidências de validade de construto para a versão brasileira da FSS-2 e, desta forma, contribuir com subsídios teóricos e empíricos para a pesquisa e a prática profissional do psicólogo brasileiro no âmbito do desporto e do exercício físico. Participaram da pesquisa 366 atletas, homens e mulheres, de 16 a 41 anos de idade, do futsal, handebol, voleibol e rugby, que disputavam os Jogos Universitários Gaúchos 2015. Os escores da FSS-2 foram submetidos à Análise Fatorial Confirmatória. Foram encontrados indicativos de validades de conteúdo, fatorial, convergente e discriminante e de consistência interna e discutidas baseadas nos dados teóricos e empíricos dessa linha de pesquisa. Conclui-se que os ajustes gerais do modelo testado foram próximos aos obtidos nos estudos originais.

Palavras-chave: flow, validade do teste, psicologia do esporte, psicologia positiva

\section{Evidencias de Validez para la Flow State Scale-2 en Atletas Universitarios}

\begin{abstract}
Resumen: El flow es un excelente estado psicológico, una experiencia muy positiva, asociado con altos niveles de rendimiento en diversas áreas de la actividad humana como la del deporte. Este estudio buscó evidencias de validez del constructo para la versión brasileña de la FSS-2 y, de esta forma, contribuir con los subsidios teóricos y empíricos para la investigación y la práctica profesional del psicólogo brasileño en el ámbito del deporte y del ejercicio físico. El instrumento proporciona nueve medidas específicas y una medida global de flow. En el estudio participaron 366 personas, hombres y mujeres, con edad de entre 16-41 años, jugadores de fútbol sala, balonmano, voleibol y rugby, que competían en los Juegos Universitarios Gaúchos 2015. Las puntuaciones de FSS-2 se sometieron a análisis factorial confirmatorio. Se encontraron indicios de validez de contenido, factorial, convergente y discriminante y de consistencia interna, que fueron analizados a partir de los datos teóricos y empíricos de esa línea de investigación. Se concluye que los ajustes generales del modelo comprobado fueron cercanos a los obtenidos en los estudios originales.
\end{abstract}

Palabras clave: flow, validación de test, psicología del deporte, psicología positiva

In the early 1970 s, Mihaly Csikszentmihalyi sought to understand the specifics of human experiences that lead to skills and expertise by examining the descriptive narrative of his research participants in order to better understand

${ }^{1}$ Universidade do Estado do Rio de Janeiro, Rio de Janeiro-RJ, Brazil ${ }^{2}$ Universidade Federal do Rio Grande do Sul, Porto Alegre-RS, Brazil Correspondence address: Jose A. E. Hernandez. Universidade do Estado do Rio de Janeiro. Instituto de Psicologia. Rua São Francisco Xavier, 524 $10^{\circ}$ andar - Maracanã. Rio de Janeiro-RJ, Brazil. CEP 20.550-900. E-mail: hernandez.uerj@gmail.com specific domains of performance. Csikszentmihalyi called flow these very positive experiences that were experienced when everything converged towards a great execution of the task and that were associated with high levels of performance in several areas. From that point on, the flow state has been studied at work, at school, in arts, in leisure, as well as in sports (Csikszentmihalyi, 2014).

Flow is a highly functional state that per se leads to good performance, wherein individuals who experience it are more motivated to perform new tasks in order to repeat the experience and face new challenges, being a motivating 
force par excellence. During this flow state, among other factors, individuals would be very concentrated and would invest all their available energy resources, thus facilitating the execution of tasks (Csikszentmihalyi, 2014). The mindset that comes with flow tends to push people to their limits, which is one of the reasons why this state is important for athletes who seek excellence.

Susan Jackson pioneered on the exploration of flow experiences in sports and found that in most elite athletes this state is explained by nine related factors: ChallengeSkill Balance, the athlete's assessment on the ability to overcome the challenge, leading the athlete to find an optimal psychological state; Action-Awareness Merging, a characteristic that refers to the automatic performance of tasks and leads to the accomplishment of the sport activity in a more fluid way, avoiding the appearance of intrusive thoughts; Clear Goals, the need to have clear goals in order to improve performance on a task; Unambiguous Feedback, when performing a task it is essential for the athlete to know whether it is done correctly; Concentration on Task, an essential characteristic of optimal mental state; Sense of Control, the perception of control and mastery of the athlete over the task he is performing; Loss of SelfConsciousness, the ability of the athlete to avoid worries and concerns over one's own ability, which helps the athlete feel more adventurous in facing the task; Time Transformation, reduced perception of time or increased perception of extra time, which can promote a more positive psychological attitude and lead to a better performance of the task; and Autotelic Experience, the intrinsic satisfaction produced by the task performed, without any particular need for an external reward (Jackson \& Csikszentmihalyi, 1999).

The Flow State Scale (FSS) was made with items acquired from research, within and outside of the sporting environment, as well as from qualitative analyses of interviews with elite athletes. The initial set of 54 items was submitted to the practitioners of sports or physical activities of varying levels of performance. In the analyses, several items with ambiguous or negative formulations were identified and replaced by clearer and more positive formulations (Jackson, 1995).

According to Jackson and Marsh (1996), the FSS was answered by practitioners of various sports, physical exercises, and performance levels. Individuals who failed to identify a flow experience or who, over the course of a year, did not experience it at least once were excluded from this study. Subsequently, these procedures were changed and the scale was recommended to be used immediately after sports and physical activities. Confirmatory Factor Analysis (CFA) of the data from Jackson and Marsh (1996) showed satisfactory adjustment in both the first order model, with nine correlated factors, as well as the second order model, with nine factors and a global flow factor. Alfas had internal consistencies ranging from 0.80 to 0.86 for the nine factors. At the end, the instrument had 36 items equally divided into nine subscales.

Doganis, Iosifidou and Vlachopoulos (2000) evaluated the FSS with Greek athletes of volleyball and handball of the second national division after a sports competition. The results showed only acceptable psychometric properties and suggested the need for scale improvements, which led Jackson and Eklund (2002) to replace five items in the original version of the FSS and to rename it to Flow State Scale -2 (FSS-2). The AFCs had good adjustments for the first and second order models, but slightly better for the first order models. The authors concluded that these results revealed acceptable factorial validity, but also acknowledged that the overall factor load on Time Transformation was weak (0.23). Thus, they recommended the use of the nine specific measures of FSS-2, which provide more information, as well as the overall measure, in special research situations.

The results of Fournier et al. (2007) replicated, with a slight advantage, the factorial structure obtained by Jackson and Eklund (2002), and the fitness of the first order model was also superior to the second order model. Again, Time was not a predominant dimension in the overall flow experience. Fournier et al. have suggested that this skill is necessary for the performance of certain sports. In those that require clear awareness of time, it can cause anxiety and interrupt the flow.

Kawabata, Mallett and Jackson (2008) found a good fitness for the nine factor and global factor models by means of FCA and concluded that the scores provided strong evidence of validity and reliability for the Japanese FSS-2. The authors also reported that item 14 was excluded from the study due to a typing error.

The development of the Dispositional Flow Scale (Marsh \& Jackson, 1999) and the Dispositional Flow Scale-2 (Jackson \& Eklund, 2002) was stimulated by the proposition that there are individual differences in frequency and intensity of flow experiments. Subsequent research has revealed that flow disposition is positively related to self-esteem, self-concept, and perceived ability (Schmidt, Shernoff, \& Csikszentmihalyi, 2014); to satisfaction with life (Asakawa, 2010); to intrinsic motivation (Türksoy, Altıncı, \& Üster, 2016); to psychological well-being (Burke, Koyuncu, \& Fiksenbaum, 2016); to the tendency to adopt active coping strategies (Hardes \& Hogeveen, 2016); and to Neuroticism and Conscientiousness, as per the Five-Factor Model (Chu, Lee, Huang, \& Lin, 2013; Ross \& Keizer, 2014; Ullén et al., 2012).

In Brazil, studies on flow and motivation in athletics (Silva, 2013), intrinsic motivation in street runners (Massarella and Winterstein, 2009), motivation, self-efficiency, perceived ability and goal orientation in volleyball were found (Gomes, Miranda, Bara Filho, \& Brandão, 2012), in parathletics (Gomes, Leite, Pedrinelli, \& Brandão, 2012), in climbers and downhill skateboarders (Vieira, Balbim, Pimentel, Hassumi, \& Garcia, 2011), in adventure tourism (Strassburger \& Macke, 2012) and in musical performance (Stocchero \& Araújo, 2012). All these studies used qualitative methods in their investigations.

So far, within the Sistema de Avaliação de Testes Psicológicos (2016) of the Brazilian Federal Council of Psychology, there is no record of favorable or unfavorable opinions on psychological tests for the sports environment. This study sought evidence of construct validity for the Brazilian version of FSS-2 and, in this way, contribute with theoretical and empirical subsidies for the research and professional practice of Brazilian psychologists in the field of sports and physical exercise. 


\section{Method}

\section{Participants}

A total of 366 university athletes were examined, ranging from 16 to 41 years of age $(M=22.5, S D=3.78), 195(53.3 \%)$ female and $171(46.7 \%)$ male, who played Futsal $(48.9 \%)$, Handball (23.5\%), Volleyball (13.9\%) and Rugby (13.7\%). The participants' practice time ranged from two months to 28 years ( $M 10$ years, $S D 6$ years) and training frequency was, on average, two hours a day, twice a week. The university students participated in the University Games Gaúchos 2015 and were related to 18 public and private institutions of higher education in several regions of the state of Rio Grande do Sul/Brazil.

\section{Instrument}

The Flow State Scale (FSS-2) by Jackson and Eklund (2002) has 36 items equally distributed into nine scales that would evaluate the following dimensions: ChallengeSkill Balance, Action-Awareness Merging, Clear Goals, Unambiguous Feedback, Concentration on Task, Sense of Control, Loss of Self-Consciousness, Time Transformation and Autotelic Experience, which together would provide an overall measure of flow. Items from the FSS-2 were answered using a five-point Likert scale, limited by the extremes "strongly disagree" (1) and "strongly agree" (5).

\section{Procedures}

Data Collection. After the consent of the coaches, the athletes were invited to participate in the research. The data were collected on the competition sites themselves immediately after the games. The collection was done in groups, by teams. Each athlete voluntarily answered the FSS-2 items, sitting on the bleachers of gymnasiums and fields, with the help of a clip board.

Data Analysis. Using SPSS, descriptive analyses were conducted to verify data distribution and, with use of the application software Analysis of Moment Structures - AMOS (Arbuckle, 2014), Confirmatory Factorial Analyses (AFCs) with the Maximum Likelihood estimation method, for verifying the factorial structure of FSS-2. The confirmatory process followed two steps (Kline, 2015): first, the first-order model with nine related factors was tested and adjusted, and then the second factor global flow factor model with nine factors was used.

In order to compare the adjustment quality of the FSS2 factorial models from this study as well as from previous studies (Fournier et al., 2007; Jackson \& Eklund, 2002; Jackson et al., 2008; Kawabata et al., 2008), the following indices were considered: Chi-squared $\left(\chi^{2}\right)$, which evaluates the magnitude of the discrepancy between the population covariance matrix and the covariance matrix of the sample. The $\chi^{2}$ is a conservative estimate of the model's fitness when the sample size is $>200$. In this case, the $\chi^{2} / g l$ ratio must be used and results $<2.0$ are considered good; the Root Mean Square Residual (RMSR) is a ratio between the square root of the error matrix and the degrees of freedom. The lower the value of the RMSR, the better adjustment the model tested will show, values $<0.08$ indicate a good fit; with Comparative Fit Index $(C F I)$ and the Non-normed Fit Index (NNFI), relative indexes that compare the fitness of the evaluated model with the basal model, values $>0.90$ indicate a good fit; the Root Mean Square Error of Approximation (RMSEA) measures discrepancy by means of degrees of freedom between sample and population estimates. Values $<0.05$ are considered to be very good; and the Expected Cross-Validation Index (ECVI) estimates the theoretical adjustment of the model with the sample used in the study as well as other similar samples. As the estimation method was Maximum Likelihood, MECVI was used. According to Modification Indices $(>11 ; p<0.001)$, re-specs were made for the model based on theoretical justifications (Marôco, 2014).

In order to estimate construct validity in the context of Structural Modeling Equations (SME), factorial validity was evaluated by the standardized weights $(\lambda)$ and individual reliability of the items $\left(\lambda^{2}\right)$. Convergent validity was evaluated by means of Average Extracted Variance (AEV) and internal consistency. Discriminant validity was determined by comparing the AEV of the factors with the square of the correlation between them. Internal consistency check was performed using Composite Reliability (CR), evaluated for each of the nine factors and the FSS-2 global factor (Hair, Black, Babin, \& Anderson, 2016; Marôco, 2014).

After examining the measurement, the associations between Age and Practice Time of Athletes as well as each of the nine dimensions of the FSS-2 were verified with use of the Pearson Correlation Coefficient. Studen"s $t$-test for independent samples compared the means of FSS-2 dimensions between men and women. The application software G-Power was used for post-hoc estimation of the power of the tests used.

\section{Ethical Considerations}

The project was submitted and approved by opinion No. 1.336.427 of the research ethics committee from the institution to which this project is affiliated. All participants in this study (judges, focus group and participating athletes) were invited to participate voluntarily in the investigation, clarified about the objectives of the study, and read and signed the Informed Consent Form according to the ethical guidelines for research involving human beings contained in Resolution CNS No. 466/12.

\section{Results}

\section{Content Validity}

The FSS-2 items were translated into Portuguese using the back-translation method by two bilingual psychologists. After the translation and consensual adjustments between the translators and researchers, the items were subjected to analysis with the support of five judges-evaluators (two 
from Psychology and three from Physical Education), doctors, researchers, professors from Brazilian public universities and with theoretical and practical knowledge in the sports field. This evaluation used the Content Validity Coefficient (CVC) method (Hernández Nieto, 2002). The judges used a scale of 1 to 5 points to assess the levels of Clarity of Language, Practical Relevance and Theoretical Relevance of each of the 36 items in the FSS-2. Based on the judges' scores, the average of each item was calculated and, using this average as basis, the CVCi of each item was calculated considering the maximum value that each item was able to receive. The calculation of the error for each item was also performed in order to eliminate possible biases of the judges.
Hernández Nieto (2002) recommended that acceptable CVCs should be $\geq 0.80$. Regarding the Clarity of Language of the 36 items of EEF-2, the $\mathrm{CVC}_{\text {clarity }}$ was calculated $=0.92$. Only item 14 of the factor Concentration on Task had $\mathrm{CVC}_{\mathrm{i}}=0.76$, in this case it was reformulated according to the judges' suggestions. As for the evaluation of Practical Pertinence and Theoretical Relevance of the FSS-2 items, $\mathrm{CVC}_{\text {totals }}$ were 0.93 and all 36 items presented $C V C=0.80$ in these dimensions. The judges also ranked each of the 36 items into the nine dimensions of FSS-2. This classification was subjected to Cohen's Kappa Coefficient, according to the criteria by Landis and Koch (1977). The indices obtained and presented in Table 1 ranged from 0.60-0.80 "substantial agreement" to $>0.80$ "almost perfect agreement" for the rankings made by the evaluators.

Table 1

Kappa Indices and Confidence Intervals for the Specific and Global Dimensions of FSS-2

\begin{tabular}{cccccccccc}
\hline F1 & F2 & F3 & F4 & F5 & F6 & F7 & F8 & F9 & FSS-2 \\
\hline \multirow{2}{*}{0.90} & \multirow{2}{*}{0.76} & 0.73 & 0.62 & 0.71 & 0.69 & 0.61 & 1.0 & 0.79 & 0.76 \\
$(0.79-1.0)$ & $(0.65-0.86)$ & $(0.63-0.84)$ & $(0.52-$ & $(0.60-$ & $(0.59-$ & $(0.51-$ & $(0.90-1.0)$ & $(0.69-$ & $(0.73-$ \\
& & & $0.73)$ & $0.81)$ & $0.79)$ & $0.72)$ & $0.90)$ & $0.80)$ \\
\hline
\end{tabular}

Note. For all indices, the significance level was $p<0.001$ and Confidence Interval, $95 \%$. F1 $=$ Challenge-skill Balance; F2 $=$ ActionAwareness Merging; F3 = Clear Goals; F4 = Unambiguous Feedback; F5 = Concentration on Task; F6 = Sense of Control; F7 = Loss of Self-Consciousness; F8 = Time Transformation; F9 = Autotelic Experience.There was also a focus group with eight university athletes, five men and three women. The objective of this group was to verify the comprehension, pertinence and adequacy of the language used for the target audience. In these discussions, FSS-2 items were considered relevant and adequate by the participants and only minor adjustments of language were made to them.

\section{Construct Validity}

During initial examination of the collected data, the absences of 47 scores were computed $(0.3 \%$ of the total), which were replaced by average. The multivariate abnormality of the data distribution was evident, the Mardia coefficient was 296.10 (normalized $=54.15$ ), but in univariate statistic the asymmetry was $< \pm 2$ and the kurtosis $< \pm 7$, which is not in an extreme violation of normality (Finney \& DiStefano, 2006).

In the context of ESM, construct validity is determined by factorial validity, convergent validity and discriminant validity, according to Hair et al. (2016) and Marôco (2014). With CFA, the maximum likelihood estimation method was used, which is robust even in the presence of a non-normal data distribution (Marôco, 2014) to test two FSS-2 models (a) with nine correlated factors and (b) with nine factors and one global factor, as shown in Figure 1.

The FCA revealed good fit indices for the correlated nine factors model of the FSS-2 (Table 2). Most items had standardized factorial weights $(\lambda)$ very close to or $>0.5$ (Table 3), except for item 14 ("There was no effort to keep my mind focused on the competition"), with standardized factorial load of 0.37. Consequently, most items had $\lambda^{2}$ near or $>0.25$, which indicates appropriate individual reliability for them, except for item 14 with 0.14 . It was decided that the model be re-specified excluding this item from analyses.

Analysis of the change indexes indicated the possibility of performing some morere-specifications in the nine correlated factors model and improve its adjustment. Correlation errors of four pairs of observed variables were detected. That is, part of the variances, which are not explained by the latent factors to which these items belong, are correlated, and these share another underlying factor not contemplated in the model. These re-specifications in the nine correlated factors model from FSS-2 caused improvements in the estimated indices (Table 2), some values remained in the "good" range, but others went to an adjustment to "very good", according to the classification by Marôco (2014).

Using $\chi^{2}$ statistics of the original nine-factor model $\left(\chi_{\mathrm{o}}^{2}\right)$ and the re-specified nine-factor model $\left(\chi_{\text {reesp }}^{2}\right)$ together with their respective degrees of freedom, the following test statistic was performed: $\Delta \chi^{2}=\chi_{0}^{2}-\chi_{\text {reesp. }}^{2}=1055,349$ $-876,503=178,846$, with $558-520=38$ degrees of freedom. In the Chi-square distribution table for $\alpha=0.05$, there is an $\chi_{0.95(38)}^{2}=53.384<\Delta \chi^{2}=178.846$, showing that the respecified correlated nine-factor model (Figure 1) fits better than the original model itself. The MECVI indicated that this respecified model would also have better validity in the investigated population, data that are presented in Table 2.

Otherwise, the CFA of the FSS-2 model with nine factors and a global dimension presented estimates (Table 2) that affected the good fit of the data for the model tested (Marôco, 2014). In addition, analysis of the modification indices revealed associations between the residues of item 21 (e21) and the Autotelic Experience factor (eEA); and between item 30 (e30) and the Sense of Control (eSC) factor. These correlations indicated that considerable parts of the 
variances of these items were not explained by the factor in which they saturated (Clear Goals). This situation could lead to questioning the theoretical model that defines what factors the items must saturate or to the exclusion of said items, since they cause correlations between factors that would be theoretically orthogonal.

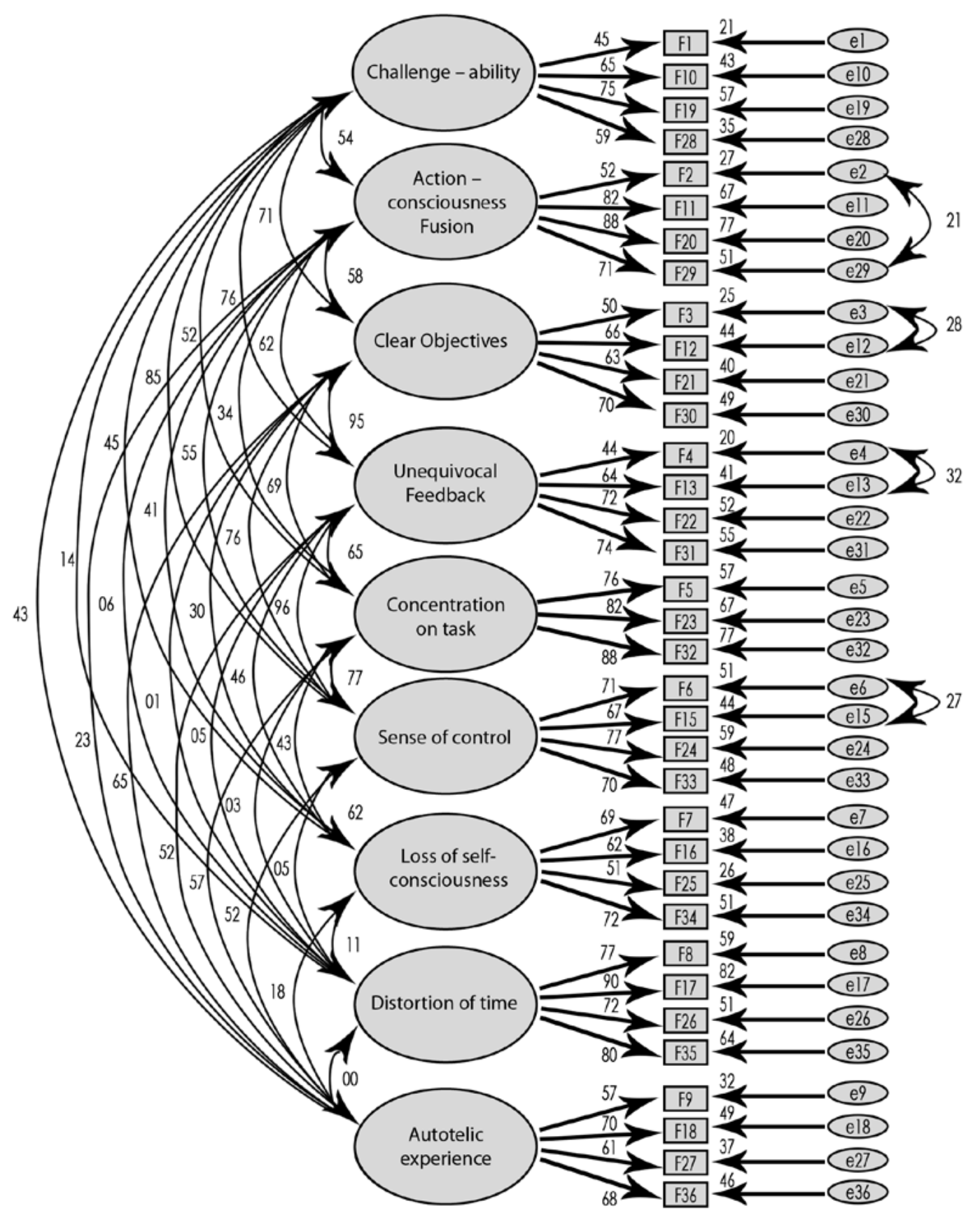

Figure 1. Re-specified factorial model diagram of nine correlated FSS-2 factors with standardized estimates.

Again, by means of $\chi^{2}$ statistics, it was possible to conduct the test $\Delta \chi^{2}=\chi_{\text {global }}^{2}-\chi_{\text {reesp. }}^{2}=1195.971-876.503=319.468$, with $585-520=65$ degrees of freedom. With these data, referring to the chi-square distribution table for $\alpha=0.05$, a value of $\chi_{0.95(65)}^{2}=84,821<\Delta \chi^{2}=319,468$ is observed, showing that the re-specified nine-factor correlated model (Figure 1) adjusted better than the hierarchical global factor model. The $M E C V I$ indicated that the respecified first-order model will also have better validity in the investigated population than the second-order model (Table 2).

As for the continuity of the analysis of the respecified first-order model of the FSS-2, convergent validity was measured by the total number of variances in the observed variables as explained by latent factors, represented by Average Variance Extracted (AVE), which ranged from 0.39 to 0.67 , data shown in Table 3 . 
Table 2

Quality Assurance Indices for FSS-2 Tested Models: Previous and Current Studies

\begin{tabular}{|c|c|c|c|c|c|c|c|c|}
\hline Study & Model & $\chi^{2}(g l)$ & $\chi^{2} / g l$ & $R M S R$ & $N N F I$ & $C F I$ & RMSEA[LO90HI90] & $M E C V I$ \\
\hline \multirow[t]{2}{*}{ Jackson \& Eklund (2002) } & First Order & $1171.03^{\mathrm{a}}(558)$ & 2.10 & - & 0.92 & 0.93 & $0.053[0.049-0.057]$ & - \\
\hline & Second Order & $1266.19^{\mathrm{a}}(585)$ & 2.16 & - & 0.91 & 0.92 & $0.055[0.050-0.059]$ & - \\
\hline \multirow[t]{2}{*}{ Fournier et al. (2007) } & First Order & $1088.42^{\mathrm{a}}(558)$ & 1.95 & - & 0.93 & 0.94 & $0.050[0.045-0.054]$ & - \\
\hline & Second Order & 1186.72 nd (585) & 2.03 & - & 0.93 & 0.93 & $0.052[0.047-0.056]$ & - \\
\hline Kawabata et al. (2008) & First Order & $806.64^{\mathrm{a}}(524)^{\mathrm{b}}$ & 1.54 & 0.04 & 0.96 & 0.96 & $0.037[0.032-0.042]$ & - \\
\hline \multirow[t]{2}{*}{ Jackson et al. (2008) } & First Order & $1332.89^{\mathrm{a}}(558)$ & 2.39 & 0.05 & 0.97 & 0.98 & $0.05^{\mathrm{c}}$ & - \\
\hline & Second Order & $1717.60^{\mathrm{a}}(585)$ & 2.94 & 0.08 & 0.96 & 0.97 & $0.06^{\mathrm{c}}$ & - \\
\hline \multirow[t]{3}{*}{ Current } & First Order & $1055.35^{\mathrm{a}}(558)$ & 1.89 & 0.05 & 0.90 & 0.91 & $0.049[0.045-0.054]$ & 3.55 \\
\hline & $\begin{array}{l}\text { First order } \\
\text { respecified }\end{array}$ & $876.50^{\mathrm{a}}(520)$ & 1.69 & 0.05 & 0.93 & 0.94 & $0.043[0.038-0.0 .48]$ & 3.07 \\
\hline & Second Order & $1195.97^{\mathrm{a}}(585)$ & 2.04 & 0.06 & 0.88 & 0.89 & $0.053[0.049-0.058]$ & 3.77 \\
\hline
\end{tabular}

Note. ${ }^{\mathrm{a}} p<0.001 .{ }^{\mathrm{b}}$ Item 14 was excluded. ${ }^{\mathrm{c}}$ Confidence interval not informed.

Table 3

Standardized Factorial Loadings, Individual Item Reliability, Composite Reliability (CR) and Average Variance Extracted (AVE) of the dimensions from the nine correlated factors model of FSS-2 after respecification

\begin{tabular}{|c|c|c|c|c|c|c|}
\hline Dimensions & Item & $\lambda$ & $\lambda^{2}$ & $\mathrm{CR}$ & VME & $\lambda^{*}$ \\
\hline \multirow[t]{4}{*}{1 Challenge-Skills Balance } & 1 & 0.45 & 0.21 & 0.71 & 0.39 & 0.82 \\
\hline & 10 & 0.65 & 0.43 & & & \\
\hline & 19 & 0.75 & 0.57 & & & \\
\hline & 28 & 0.59 & 0.35 & & & \\
\hline \multirow[t]{4}{*}{2 Action-Awareness Merging } & 2 & 0.52 & 0.27 & 0.83 & 0.56 & 0.61 \\
\hline & 11 & 0.82 & 0.67 & & & \\
\hline & 20 & 0.88 & 0.77 & & & \\
\hline & 29 & 0.71 & 0.51 & & & \\
\hline \multirow[t]{4}{*}{3 Clear Goals } & 3 & 0.50 & 0.25 & 0.72 & 0.40 & 0.96 \\
\hline & 12 & 0.66 & 0.44 & & & \\
\hline & 21 & 0.63 & 0.40 & & & \\
\hline & 30 & 0.70 & 0.49 & & & \\
\hline \multirow[t]{4}{*}{4 Unambiguous Feedback } & 4 & 0.44 & 0.19 & 0.74 & 0.42 & 0.94 \\
\hline & 13 & 0.64 & 0.41 & & & \\
\hline & 22 & 0.72 & 0.52 & & & \\
\hline & 31 & 0.74 & 0.55 & & & \\
\hline \multirow[t]{3}{*}{5 Concentration On Task } & 5 & 0.76 & 0.57 & 0.86 & 0.67 & 0.74 \\
\hline & 23 & 0.82 & 0.67 & & & \\
\hline & 32 & 0.88 & 0.76 & & & \\
\hline \multirow[t]{4}{*}{6 Sense of Control } & 6 & 0.71 & 0.51 & 0.80 & 0.51 & 0.96 \\
\hline & 15 & 0.66 & 0.44 & & & \\
\hline & 24 & 0.77 & 0.59 & & & \\
\hline & 33 & 0.70 & 0.48 & & & \\
\hline \multirow[t]{4}{*}{7 Loss or Inhibition of Self-Awareness } & 7 & 0.69 & 0.47 & 0.73 & 0.41 & 0.54 \\
\hline & 16 & 0.62 & 0.38 & & & \\
\hline & 25 & 0.51 & 0.26 & & & \\
\hline & 34 & 0.72 & 0.51 & & & \\
\hline \multirow[t]{4}{*}{8 Time Transformation } & 8 & 0.76 & 0.58 & 0.87 & 0.64 & 0.03 \\
\hline & 17 & 0.90 & 0.82 & & & \\
\hline & 26 & 0.72 & 0.51 & & & \\
\hline & 35 & 0.80 & 0.63 & & & \\
\hline \multirow[t]{4}{*}{9 Autotelic Experience } & 9 & 0.57 & 0.32 & 0.73 & 0.41 & 0.58 \\
\hline & 18 & 0.70 & 0.49 & & & \\
\hline & 27 & 0.61 & 0.37 & & & \\
\hline & 36 & 0.68 & 0.46 & & & \\
\hline
\end{tabular}

Note. $\lambda=$ Factorial Weight; $\lambda^{2}=$ Standardized Factorial Weight. CC: Composite Reliability.

$A V E=$ Average Variance Extracted $*$ Second order hierarchical model values. 
In the SEM, discriminant validity is defined by the non-presentation of considerable correlations between the constructs of the model. In this study, discriminant validity was verified by the method of comparing the square of the correlations between the nine factors of the FSS-2 and the
AVE of the factors. In all comparisons, AVE values were higher than the square of the correlations between factors, indicating discriminant validity (Hair et al., 2016; Marôco, 2014), except for the correlation between the factors Clear Goals and Unambiguous Feedback. Data are shown in Table 4.

Table 4

Discriminant Validity Matrix

\begin{tabular}{|c|c|c|c|c|c|c|c|c|c|}
\hline & F1 & $\mathrm{F} 2$ & F3 & $\mathrm{F} 4$ & F5 & F6 & F7 & $\mathrm{F} 8$ & F9 \\
\hline F1-Challenge-Skill & 0.39 & & & & & & & & \\
\hline F2- Action-Awareness Merging & 0.16 & 0.56 & & & & & & & \\
\hline F3-Clear Goals & 0.25 & 0.19 & 0.40 & & & & & & \\
\hline F4-Unambiguous Feedback & 0.23 & 0.20 & 0.46 & 0.42 & & & & & \\
\hline F5-Concentration on Task & 0.17 & 0.11 & 0.27 & 0.26 & 0.67 & & & & \\
\hline F6-Sense of Control & 0.38 & 0.22 & 0.38 & 0.38 & 0.41 & 0.51 & & & \\
\hline F7-Loss of Self-Awareness & 0.11 & 0.11 & 0.05 & 0.11 & 0.15 & 0.22 & 0.41 & & \\
\hline F8-Time Transformation & 0.01 & 0.01 & 0.00 & 0.00 & 0.00 & 0.00 & 0.01 & 0.64 & \\
\hline F9-Autotelic Experience & 0.08 & 0.02 & 0.19 & 0.13 & 0.16 & 0.17 & 0.01 & 0.00 & 0.41 \\
\hline
\end{tabular}

Note. AVE values are shown diagonally in bold.

The reliability of the factors and the overall size of the FSS-2 was calculated using Composite Reliability (CR). Internal consistency values were estimated that represent appropriate conditions for all dimensions, since all indices exceeded 0.70 (Hair et al., 2016), except for the factor Clear Goals, with 0.69 (Table 3).

Pearson's Correlation Coefficient found significant positive relationships $(p<0.05)$ between most FSS-2 factors and Sports Practice Time, except for Concentration on Task, Time Transformation and Autotelic Experience. However, these calculated correlation coefficients $(r)$ ranged from 0.11 to 0.24 ( $R^{2}$ from 0.01 to 0.06 ). Otherwise, only the factors Challenge-Skill Balance, Sense of Control and Loss of SelfConsciousness of the FSS-2 showed statistically significant correlations with the Age of the participants, and in these cases the $r$ coefficients ranged from 0.13 to $0.16\left(R^{2}\right.$ from 0.02 to 0.03 ). The power of the tests was around 0.65 to 0.93 .

Student's $t$-Test for independent samples compared the means obtained in the FSS-2 factors between male and female athletes. According to the results, significant statistical differences were determined for Unambiguous Feedback, $t(364)=2,386 ; p<0.05 ; d=0.25$, and Sense of Control, $t(364)=2,276 ; p 0.05 ; d=0.24$. With both factors, the averages of men surpassed those of women. With the remaining factors, no statistically significant differences were detected between the means per participant's sex and the calculated $d_{s}$ ranged from 0.03 to 0.22 . The power of the tests calculated a posteriori, in general, was around 0.61 .

\section{Discussion}

The results of the content validation process for the adaptation of FSS-2 to the Brazilian culture involved qualitative and quantitative procedures. The translation of the scale items into Portuguese, the CVC (Hernández Nieto, 2002), Cohen's Kappa and the focus group provided evidence of content validity for the measurement. In general, the coefficients obtained were satisfactory and indicated that the items could competently operate on the constructs they represented.

Considering Marôco's criteria (2014), the estimated indexes for the re-specified nine-factor correlated model of the Brazilian version of FSS-2 revealed a good fit of empirical data, significantly better than the original first and second order models tested (Table 2). Compared to previous studies (Jackson \& Eklund, 2002; Marsh \& Jackson, 1999) and adaptation studies (Fournier et al., 2007), the current results corroborate them.

In their analyzes, Jackson and Eklund (2002) and Marsh and Jackson (1999) also found that the adjustments of the first order models were superior to those of second order models, however, in these studies, these differences were considered small. Vlachopoulos, Karageorghis and Terry (2000) reported an inadequate adjustment for the hierarchical model more similar to that occurred in the present study. In this investigation, the weak correlations between the factors Loss of Self-Consciousness and Time Transformation with the global factor were blamed for the weaker or inadequate performance of the second-order model. In the current study, in a more radical manner, the factor Time Transformation showed very weak correlation with the global dimension (0.03), which undoubtedly did not contribute to a good fit of the hierarchical model. Fournier et al. (2007) suggested that Time Transformation may be necessary for the performance of certain sporting modalities, but in other sports that require a clear awareness of the time this ability could generate anxiety and interrupt flow.

Item 14 ("There was no effort to keep my mind focused on competition") showed the weakest factor weight among 
all 36 items (Table 3), revealing that only $14 \%$ of the variance was determined by the Concentration on Task factor, below a more adequate value to safeguard the factorial validity and the individual reliability of the item. In the content validation process, item 14 obtained $\mathrm{CVC}_{\mathrm{i}}=0.76$ and was reformulated by the judges' suggestions, however, it seems that this was not enough to properly operationalize the construct. Coincidentally, Kawabata et al. (2008) excluded the same item, but for a different reason, typing error.

Modification indices showed correlations between the measurement errors of four pairs of items: factor ActionAwareness Merging, items 2 ("I made the correct moves without thinking about how to make them") and 29 ("I made the moves without thinking, spontaneously and automatically"); factor Unambiguous Feedback, items 3 ("I clearly knew what he wanted to do") and 12 ("I had a clear sense of what I wanted to do"); and items 4 ("it was very clear to me how my performance was") and 13 ("I was aware of how my performance was"); factor Sense of Control, items 6 ("I felt I had control over what I was doing") and 15 ("I felt I could control what I was doing"). As can be seen, each of the pairs of items was originally designed to represent the same construct and are alternative formulations of the same content, which may explain the correlations found between their errors and the inclusion of additional trajectories to the FSS-2 model (Figure 1).

Convergent validity was measured according to the AVE, which reveals the total amount of variance of the observed variables as explained by the latent variable, recommended values for a construct must be equal to or above 0.50 . Values of AVEs were unsatisfactory, being slightly below that recommended in some constructs (Table 3). However, the CRs for each model construct, which are also indications of convergent validity, presented values that met the recommendations (Hair et al., 2016).

In general terms, measures of AVEs were higher than the squares of correlations between the latent FSS-2 factors. These results suggest that each modeled factor represented a specific flow value, which fit the model adequately and discriminated from the values of the other factors. However, in the case of the factors Clear Goals and Unambiguous Feedback, the correlation between them was higher than AVE (Table 3), not indicating sufficient discrimination.

Examinations of the relationships between Sex, Age and Sports Practice Time of the athletes with the dimensions of FSS-2 revealed some results with statistical significance $(p<0.05)$. However, calculated effect sizes were small (Cohen, 1992) in all tests, including those with nonsignificant $p$-values. These data associated with high power values indicated that these effects are probably small and of little theoretical significance.

The results showed that the data of Brazilian university athletes reasonably represented the respecified model of nine first order factors of the FSS-2. In addition to evaluating the model as a whole, examination of the fit of individual parameter estimates, the convergent and discriminant validity, and the estimates of internal consistency can also be considered satisfactory.
Studies have shown the effectiveness of flow state training programs for the performance of elite athletes. Undoubtedly, this type of psychological intervention requires a measure that can monitor these training processes and generate evidence of their effectiveness. According to the systematic literature review of Norsworthy, Gorczynski and Jackson (2017), this has been done with the assistance of FSS-2 in most of these interventions. Therefore, the Brazilian version of FSS- 2 produced in this study can be a useful tool in the work of the sports psychologist.

The current results revealed general adjustments of the flow model close to those obtained in the original and subsequent studies (Fournier et al., 2007; Jackson \& Eklund, 2002; Marsh \& Jackson, 1999), which is evidence of the validity of this Brazilian FSS adaptation -2. However, for the second order model of the FSS-2, the current data did not produce such a fit adjustment. We recommend that future studies contribute with improvements to the instrument, perhaps improving the formulation of items, especially 14 (excluded by poor psychometric performance), and including larger samples, covering several Brazilian regions, sports modalities and performance levels.

\section{References}

Arbuckle, J. L. (2014). IBM SPSS AMOS 23.0. User's Guide. Crawfordville, FL: IBM.

Asakawa, K. (2010). Flow experience, culture, and wellbeing: How do autotelic Japanese College students feel, behave, and think in their daily lives? Journal of Happiness Studies, 11(2), 205-223. doi:10.1007/s10902-008-9132-3

Burke, R. J., Koyuncu, M., \& Fiksenbaum, L. (2016). Flow, work satisfactions and psychological well-being among nurses in Turkish hospitals. Archives of Nursing Practice and Care, 2(1), 010-017. doi:10.17352/anpc.000007

Chu, L.-C., Lee, C.-L., Huang, K.-C., \& Lin, J.-H. (2013). How personality traits mediate the relationship between flow experience and job performance. The Journal of International Management Studies, 8(1), 33-46. Retrieved from http:// www.jimsjournal.org/4\%20Chen-Lin\%20Lee.pdf

Cohen, J. (1992). “A power primer”. Psychological Bulletin 112(1), 155-159. doi:10.1037/0033-2909.112.1.155.

Csikszentmihalyi, M. (2014). Flow and the foundations of positive psychology: The collected works of Mihaly Csikszentmihalyi. New York, NY: Springer.

Doganis, G., Iosifidou, P., \& Vlachopoulos, S. (2000). Factor structure and internal consistency of the Greek version of the Flow State Scale. Perceptual and Motor Skills, 91(3), 1231-1240. doi:10.2466/pms.2000.91.3f.1231

Finney, S. J., \& DiStefano, C. (2006). Non-normal and categorical data in structural equation modeling. In G. R. Hancock \& R. O. Mueller (Eds.), Structural equation modeling: A second course (pp. 269-314). Greenwich, CT: Information Age. 
Fournier, J., Gaudreau, P., Demontrond-Behr, P., Visioli, J., Forest, J., \& Jackson, S. (2007). French translation of the Flow State Scale-2: Factor structure, cross-cultural invariance, and associations with goal attainment. Psychology of Sport and Exercise, 8(6), 897-916. doi:10.1016/j.psychsport.2006.07.007

Gomes, S. S., Leite, G. S., Pedrinelli, V., \& Brandão, M. R. F. (2012). Flow no para-atletismo [Flow in para-athletics]. Motricidade, 8(Supl. 2), 985-992. Retrieved from https:// www.redalyc.org/pdf/2730/273023568124.pdf

Gomes, S. S., Miranda, R., Bara Filho, M. G., \& Brandão, M. R. F. (2012). O fluxo no voleibol: Relação com a motivação, autoeficácia, habilidade percebida e orientação às metas [The flow in volleyball: Relationship with motivation, self-efficacy, perceived ability and goal orientation]. Revista da Educação Física/UEM, 23(3), 379-387. doi:10.4025/reveducfis.v23i3.17024

Hair, J. F., Jr., Black, W. C., Babin, B. J., \& Anderson, R. E. (2016). Multivariate data analysis (7th ed.). Upper Saddle River, NJ: Prentice Hall.

Hardes, J., \& Hogeveen, B. (2016). Flow, skilled coping, and the sovereign subject: Toward an ethics of being-with in Sport. Journal Sport, Ethics and Philosophy, 10(3), 283294. doi:10.1080/17511321.2016.1219765

Hernández Nieto, R. A. (2002). Contributions to statistical analysis. Mérida, Venezuela: Universidad de Los Andes.

Jackson, S. A. (1995). Factors influencing the occurrence of flow state in elite athletes. Journal of Applied Sport Psychology, 7(2), 138-166. doi:10.1080/10413209508406962

Jackson, S. A., \& Csikszentmihalyi, M. (1999). Flow in sports: The keys to optimal experiences and performances. Champaign, IL: Human Kinetics.

Jackson, S. A., \& Eklund, R. C. (2002). Assessing flow in physical activity: The Flow State Scale-2 and Dispositional Flow Scale-2. Journal of Sport \& Exercise Psychology, 24(2), 133-150. doi:10.1123/jsep.24.2.133

Jackson, S. A., \& Marsh, H. W. (1996). Development and validation of a scale to measure optimal experience: The Flow State Scale. Journal of Sport \& Exercise Psychology, 18(1), 17-35. doi:10.1123/jsep.1.18.17

Jackson, S. A., Martin, A. J., \& Eklund, R. C. (2008). Long and Short Measures of Flow: The Construct Validity of the FSS-2, DFS-2, and New Brief Counterparts. Journal of Sport and Exercise Psychology, 30(5), 561-587. doi: 10.1123/jsep.30.5.561

Kawabata, M., Mallet, C. J., \& Jackson, S. A. (2008). The Flow State Scale-2 and Dispositional Flow Scale-2: Examination of factorial validity and reliability for Japanese adults. Psychology of Sport and Exercise, 9(4), 465-485. doi:10.1016/j.psychsport.2007.05.005
Kline, R. B. (2015). Principles and practice of structural equation modeling. New York, NY: Guilford.

Landis, J. R., \& Koch, G. G. (1977). The measurement of observer agreement for categorical data. Biometrics, 33(1), 159-174. doi:10.2307/2529310

Marôco, J. (2014). Análise de equações estruturais. Fundamentos teóricos, software \& aplicações [Analysis of structural equations. Theoretical fundamentals, software \& applications]. Pêro Pinheiro, Portugal: ReportNumber.

Marsh,H.W., \& Jackson, S.A.(1999). Flow experienceinsport: Construct validation of multidimensional, hierarchical state and trait responses. Structural Equation Modelling, 6(4), 343-371. doi:10.1080/10705519909540140

Massarella, F. L., \& Winterstein, P. J. (2009). A motivação intrínseca e o estado mental flow em corredores de rua [Intrinsic motivation and the mental state flow in street runners]. Movimento, 15, 45-68. Retrieved from http://www.seer.ufrgs.br/index.php/Movimento/article/ view/2659/5134

Norsworthy, C., Gorczynski, P., \& Jackson, S. A. (2017). A systematic review of flow training on flow states and performance in elite athletes. Graduate Journal of Sport, Exercise \& Physical Education Research, 6, 1628. Retrieved from https://www.worc.ac.uk/gjseper/ documents/Flow_states_and_performance_in_elite_ athletes_6_16-28.pdf

Ross, S. R., \& Keiser, H. N. (2014). Autotelic personality through a five-factor lens: Individual differences in flowpropensity. Personality and Individual Differences, 59, 3-8. doi:10.1016/j.paid.2013.09.029

Schmidt, J. A., Shernoff, D. J., \& Csikszentmihalyi, M. (2014). Individual and situational factors related to the experience of flow in adolescence. In M. Csikszentmihalyi, Applications of flow in human development and education. The collected works of Mihaly Csikszentmihalyi (pp. 379-405). New York, NY: Springer.

Silva, M. V. (2013). Estado mental flow e motivação no atletismo: Dos velocistas aos ultramaratonistas [Mental state flow and motivation in athletics: From sprinters to ultramarathonists] (Dissertação de mestrado). Retrieved from https://repositorio.ufjf.br/jspui/bitstream/ ufjf/1473/1/marcusviniciusdasilva.pdf

Sistema de Avaliação de Testes Psicológicos. (2016). Testes Psicológicos. Lista Completa dos Testes [Psychological tests. Complete Test List]. Retrieved from http://satepsi. cfp.org.br/listaTeste.cfm

Stocchero, M. A., \& Araújo, R. C. (2012). Apreciação musical e envolvimento: Um estudo sob a perspectiva da teoria do fluxo [Musical appreciation and involvement: A study from the perspective of flow theory]. Revista Nupeart, 10, 8-29. doi:10.5965/2358092510102012008 
Strassburger, N. C., \& Macke, J. (2012). Dimensões de análise da experiência do flow no turismo de aventura: Rafting em Nova Roma do Sul (RS/Brasil) [Dimensions of analysis of the experience of flow in adventure tourism: Rafting in Nova Roma do Sul (RS/Brazil)]. Revista Turismo Visão e Ação, 14(2), 150-163. doi:10.14210/rtva.v14n2.p150-163

Türksoy, A., Altınc1, E. E., \& Üster, U. (2016). Relationship between motivation and dispositional flow state on football players participating in the U13-U16 football leagues. Procedia - Social and Behavioral Sciences, 185 , 301-306. doi:10.1016/j.sbspro.2015.03.423

Ullén, F., Manzano, O., Almeida, R., Magnusson, P. K. E., Pedersen, N. L., Nakamura, J., ... Madison, G. (2012). Proneness for psychological flow in everyday life: Associations with personality and intelligence. Personality and Individual Differences, 52(2), 167-172. doi:10.1016/j.paid.2011.10.003

Vieira, L. F., Balbim, G. M., Pimentel, G. G. A., Hassumi, M. Y. S. S., \& Garcia, W. F. (2011). Estado de flow em praticantes de escalada e skate downhill [State of in climbing and skateboarding downhill]. Motriz, 17(4), 591-599. doi:10.1590/S1980-65742011000400003

Vlachopoulos, S. P., Karageorghis, C. I., \& Terry, P. C. (2000). Hierarchical confirmatory factor analysis of the Flow State Scale in exercise. Journal of Sports Sciences, 18(10), 815-823. doi:10.1080/026404100419874

José Augusto Evangelho Hernandez is a Professor of the Instituto de Psicologia of the Universidade do Estado do Rio de Janeiro, Rio de Janeiro-RJ, Brazil.

Rogério da Cunha Voser is a Professor of the Escola Superior de Educação Física of the Universidade Federal do Rio Grande do Sul, Porto Alegre-RS, Brazil.

\section{Authors' Contribution:}

All authors made substantial contributions to the conception and design of this study, to data analysis and interpretation, and to the manuscript revision and approval of the final version. All the authors assume public responsability for content of the manuscript.

Received: Nov. 19, 2016

1st Revision: May 13, 2018

2nd Revision: May 28, 2018

Approved: Jun. 24, 2018

How to cite this article:

Hernandez, J. A. E., \& Voser, R. C. (2019). Validity evidence for the flow state scale-2 with Athletes university. Paidéia (RibeirãoPreto), 29, e2909. doi: http://dx.doi.org/10.1590/1982-4327e2909 